Article

\title{
From by-Product to Unconventional Vegetable: Preliminary Evaluation of Fresh Fava Hulls Highlights Richness in L-Dopa and Low Content of Anti-Nutritional Factor
}

\author{
Massimiliano Renna ${ }^{1, *(1)}$, Francesca De Cillis ${ }^{2, *}$, Beniamino Leoni $^{2}$, Ermelinda Acciardi $^{2}$ and \\ Pietro Santamaria ${ }^{2}$ (D) \\ 1 Institute of Sciences of Food Production (ISPA), CNR, via Amendola 122/O, 70126 Bari, Italy \\ 2 Department of Agricultural and Environmental Science, University of Bari Aldo Moro, via Amendola 165/A, \\ 70126 Bari, Italy; beniamino.leoni@uniba.it (B.L.); ermelinda.88@live.it (E.A.); \\ pietro.santamaria@uniba.it (P.S.) \\ * Correspondence: massimiliano.renna@ispa.cnr.it (M.R.); francescadecillis@gmail.com (F.D.C.); \\ Tel.: +39-080-5929306 (M.R.)
}

Received: 16 January 2020; Accepted: 5 February 2020; Published: 7 February 2020

check for updates

\begin{abstract}
Faba bean hulls are a by-product, generated from the processing of beans and usually disposed of as waste, utilized in some recipes of Italian traditional cuisine. In this research, a quality evaluation of faba hulls in six genotypes (four local varieties- 'Cegliese', 'Iambola', 'San Francesco' and 'FV5' - and two commercial ones-'Aguadulce supersimonia' and 'Extra-early purple') of faba bean (Vicia faba L. var. major Harz) for fresh consumption grown with two plant densities (4.16 and 2.08 plants $\mathrm{m}^{-2}$ ) was carried out. For all the measured parameters, the statistical analysis reveals that the interaction between plant density and genotype was not significant. On the other hand, independently of the genotype, the higher the plant's density the higher was the pods' yield per unit area, while the average percentage of hulls was of $75 \%$ with little differences between genotypes. All genotypes showed a low content of vicine (12.4 mg $\left.100 \mathrm{~g}^{-1} \mathrm{FW}\right)$, a well know favism-inducing factor, and a very high phenols content (between 443 and $646 \mathrm{mg} 100 \mathrm{~g}^{-1} \mathrm{FW}$ ) and levo-dihydroxy phenylalanine (L-dopa - on average $170 \mathrm{mg} 100 \mathrm{~g}^{-1} \mathrm{FW}$ ), used for the treatment of patients affected by Parkinson's disease. In conclusion, this study highlights the good potential of faba hulls as unconventional vegetable, suggesting its use as a new functional food in the daily diet and also for patients with Parkinson's disease.
\end{abstract}

Keywords: agrobiodiversity; ascorbic acid; food waste; functional food; local varieties; phenols; plant density; Vicia faba L.; vicine

\section{Introduction}

Faba bean (Vicia faba L.), also known as broad bean, is widely consumed worldwide for its edible seeds containing a considerable amount of carbohydrates and proteins as well as several other compounds such as fibre, lecithin, choline, minerals and secondary metabolites [1]. Like for other pulses (legumes), faba beans are used in many countries as dry seeds for the high protein content, making them excellent meat substitutes, suitable for vegan and vegetarian diets as well as for reducing the consumption of animal-based food. At the same time, a part of these legumes is aimed at consumption as fresh vegetables, characterized by immature seeds with a higher content of water and lesser protein and starch percentage than dry seeds (mature), but with a greater amount of functional substances such as phenols, chlorophylls, carotenoids and vitamins [2]. For example, De Cillis et al. [3] found a 
content of ascorbic acid ranging from about 380 to about $700 \mathrm{mg} 100 \mathrm{~g}^{-1}$ fresh weight (FW) as well as an interesting L-dopa content, a non-protein amino acid usually used for the treatment of Parkinson's disease and other disease [4]. Unfortunately, it should be considered that nowadays faba beans do not receive a right attention, because they contain some anti-nutritional factors such as vicine and convicine which can cause acute haemolysis phenomena subject with glucose-6-phosphate-dehydrogenase (G6PD) deficiency [5].

An important aspect of legume immature seeds used as vegetables regards their use, since hulls are removed for using seeds as a fresh food or processing them as frozen or canned food [6,7]. As a consequence, a big mass of hulls (about $70 \%$ of the total fava bean yield from the field) is generated as by-products, usually disposed of as waste. To this regards, it is interesting to highlight that like for summer squash greens, faba greens and offshoots of globe artichoke [8], also faba hulls can be used as vegetables, instead of being considered as by-products. As a matter of fact, in some areas of Italy boiled faba hulls are traditionally used to prepare some dishes such as first and main courses [9]. The culinary use of faba hulls in Italy, like other vegetable by-products, was made in the past during the periods of poverty and food scarcity, allowing to valorise by-products as "unconventional vegetables" [8]. On the other hand, considering their nutritional traits, nowadays these unconventional vegetables could satisfy the demand for high-quality foods found on ago-biodiversity [10]. It is important to highlight that functional foods contain components, nutrients, or bioactive compounds exerting selective beneficial effects on one or more functions of the organism. In this context, health claims can be considered as important value-added features for consumers and therefore for the food industry, since they can give a competitive advantage to a food product and can differentiate food products in the market. Thus, it could be very interesting to assess the quality as well as healthy compounds of these unconventional vegetables.

Since information in literature on faba hulls are scarce, the aim of this research was to assess some nutritional traits and bioactive compounds of faba hulls for providing an overview related to their potential as a new functional food.

\section{Materials and Methods}

\subsection{Cropping Details and Sampling Procedures}

Six genotypes of Vicia faba L. were used: four local varieties (Iambola, San Francesco, FV5, Cegliese) and two commercial ones (Extra-early purple and Aguadulce supersimonia). Plants were grown in a $555 \mathrm{~m}^{2}$ open field at "La Noria" experimental farm of the Institute of Sciences of Food Production of the Italian National Research Council, located in Mola di Bari (Ba, Italy), $24 \mathrm{~m}$ above sea level, $41^{\circ} 03^{\prime} \mathrm{N}$, $17^{\circ} 04^{\prime}$ E. Sowing was carried out in Autumn 2017, by using two plant densities for the production of broad beans for fresh consumption: (i) high $\left(4.16\right.$ plants $\mathrm{m}^{-2}-80 \mathrm{~cm}$ between rows and $30 \mathrm{~cm}$ within the row); (ii) low (2.08 plants $\mathrm{m}^{-2}-160 \mathrm{~cm}$ between rows and $30 \mathrm{~cm}$ within the row). A split-plot design (plant density in the main plots and the genotypes in the subplots) with three replications; each elemental parcel contained 30 plants for both densities. Plants were grown without fertilization, while a supplemental irrigation was performed only between sowing and emergence of seedling. Four harvests were carried out between April and May 2018 (10/4, 18/4, 24/4, 4/5), according to the progressive ripening of the pods. At each harvest, the pods were weighed and counted to calculate the cumulative yield. Moreover, representative samples from each harvest were used to determine the dry weight. Samples of the 2 nd harvest were used for physical and chemical analysis.

\subsection{Physical Analysis}

Colour analysis (CIELab colour scale) and total soluble solids (TSS) content of hulls were carried out by using a colorimeter (CR-400, Konica Minolta, Osaka, Japan) and a refractometer DBR45 (XS Instruments, Carpi, Italy) according to the procedure described by De Cillis et al. [3]. Each measurement was carried out in triplicate by using 30 hulls per sample. 
In regards to colour analysis, the colorimeter was calibrated with a standard reference with values $\mathrm{L}, a^{*}$ and $b^{*}$ of $97.82,1.27$ and 1.35 , respectively. $\mathrm{L}$ represents the lightness value; $a^{*}$ represents the red/green index; $b^{*}$ represents the yellow/blue index. Hue angle $\left(\mathrm{h}^{\circ}=\tan -1\left[b^{*} / a^{*}\right]\right)$ and saturation or chroma $\left(\mathrm{C}=\left[a^{* 2}+b^{* 2}\right]^{1 / 2}\right)$ were then calculated from the primary $\mathrm{L}, a^{*}$ and $b^{*}$ readings.

Regarding TSS content the analysis were carried out on hull's liquid extract and results were expressed in ${ }^{\circ}$ Brix.

For the dry weight (DW) determination, samples were maintained in an air oven at $105^{\circ} \mathrm{C}$ until constant weight.

\subsection{Total Titratable Acidity, $\mathrm{pH}$ and Crude Protein Content}

Titratable acidity (TA) and $\mathrm{pH}$ were measured according to the procedure described by De Cillis et al. [3] by using a $\mathrm{pH}$ meter Model 507 (Crison, Milan, Italy), while the crude protein content $(\mathrm{N} \times 6.25)$ was determined according to the AOAC method 955.04 [11].

\subsection{Ascorbic Acid Content and Total Phenols}

The ascorbic acid determination was performed, according to the procedure described by De Cillis et al. [3]. Briefly, $5 \mathrm{~g}$ of sample were placed in a centrifuge tube with $50 \mathrm{~mL}$ of $3 \%$ metaphosphoric acid at $4{ }^{\circ} \mathrm{C}$. The solution was homogenized and then centrifuged for $10 \mathrm{~min}$ at $4000 \mathrm{rpm}$. A $0.5 \mathrm{~mL}$ aliquot of the supernatant was filtered with a $0.22 \mu \mathrm{m}$ Nylon ${ }^{\circledR}$ filter (Fisher Scientific ${ }^{\mathrm{TM}}$ Whatman, Ma, USA). The HPLC analysis was performed using an Agilent 1100 quaternary pump and an Agilent 1260 UV detector (Agilent Thecnologies, Santa Clara, CA, USA). The chromatographic separation was performed on a Zorbax SB column $(25 \mathrm{~cm} \times 4.6 \mathrm{~cm}, 5 \mu \mathrm{m})$ with binary elution gradient, using the following solutions for the mobile phase: solution (A) KH2PO4 $20 \mathrm{mM}$ brought to $\mathrm{pH} 2.5$ with O-phosphoric acid and solution (B) $60 \%$ methanol and $40 \%$ acetonitrile. The gradient was set according to the following program: for $2 \mathrm{~min} 5 \% \mathrm{~B}$, from 3 to $13 \mathrm{~min} 25 \% \mathrm{~B}$, from 14 to $18 \mathrm{~min} 90 \% \mathrm{~B}$, from 19 to $25 \mathrm{~min} 5 \% \mathrm{~B}, 1 \mathrm{~mL} / \mathrm{min}$ is the speed of the flow and $10 \mu \mathrm{L}$ the volume of injection of the sample. The test was conducted by monitoring the absorbance signal at $210 \mathrm{~nm}$. Peak identification and calibration was performed using the pure L-Ascorbic acid standard of Sigma-Aldrich.

For total phenols (TP), the extraction procedure reported by Renna et al. [12] was used, while the procedure described by De Cillis et al. [3] was used for TP quantification. Briefly, $0.45 \mathrm{~g}$ of lyophilized sample were homogenized in a methanol/water solution $(80: 20 \mathrm{v} / \mathrm{v})$ for $1 \mathrm{~min}$ and then centrifuged at $6440 \times \mathrm{g}$ for $5 \mathrm{~min}$ at $4{ }^{\circ} \mathrm{C}$. On each extract the soluble phenol content was determined by using a colorimetric method. A total of $250 \mu \mathrm{L}$ of Folin-ciocalteu solution and $750 \mu \mathrm{L}$ of $7 \% \mathrm{NaCO}_{3}$, placed on vortex for $30 \mathrm{~s}$ and incubated for $8 \mathrm{~min}$ at room temperature were added to $50 \mu \mathrm{L}$ of the sample and $3 \mathrm{~mL}$ of distilled water. Then, $950 \mu \mathrm{L}$ of distilled water were added to the mixture and left at room temperature for $2 \mathrm{~h}$ in the dark. The absorbance was measured at $765 \mathrm{~nm}$ with T60U spectrophotometer (PG Instruments, Leicestershire, UK) and results were expressed as mg of gallic acid equivalents (GAE) per $100 \mathrm{~g}$ FW.

\subsection{Chlorophylls and Carotenoid Content}

The content of chlorophylls and total carotenoids was determined according to the method described by Albanese et al. [13], by using a T60U spectrophotometer (PG Instruments, Leicestershire, $\mathrm{UK})$. Briefly, $2 \mathrm{~g}$ of sample were homogenized in $10 \mathrm{~mL}$ of acetone/water $(80: 20 \mathrm{v} / \mathrm{v})$ and then centrifuged at $4000 \times \mathrm{g}$. The absorbance of the extract was measured at 646,663 and $470 \mathrm{~nm}$.

\subsection{Content of Vicine and L-dopa}

Vicine and L-dopa content were determined according to the procedure described by De Cillis et al. [3]. Briefly, $5 \mathrm{~g}$ of sample were extracted with $50 \mathrm{~mL}$ of perchloric acid $(5 \% w / v)$ by homogenizing for $5 \mathrm{~min}$ at $4{ }^{\circ} \mathrm{C}$. The extract was centrifuged and filtered through a $0.22 \mu \mathrm{m}$ filter (Millipore Co., Bedford, MA, USA) to remove any suspended material. For the HPLC analysis a chromatograph 
(Agilent 1100 quaternary pump) equipped with a UV-visible detector (Agilent 1260) at $280 \mathrm{~nm}$ was used. The chromatographic conditions were as follows: column C18 (Supelcosil LC, $250 \times 4.6 \mathrm{~mm}$, $5 \mu \mathrm{m}$, Supelco) with binary elution gradient at $1.0 \mathrm{~mL} / \mathrm{min}$, based on water ( $\mathrm{H} 2 \mathrm{O})$ and acetonitrile $(\mathrm{ACN})$, both containing $0.1 \%(v / v)$ of formic acid. The program adopted for the separation was: $0-2$ min isocratic $0 \% \mathrm{ACN} ; 2-3 \mathrm{~min}$ from 0 to $10 \% \mathrm{ACN} ; 3-8 \mathrm{~min}$ isocratic at $10 \% \mathrm{ACN} ; 8-10 \mathrm{~min}$ from $10 \%$ to $90 \% \mathrm{ACN} ; 10-15 \mathrm{~min}$ at $90 \% \mathrm{ACN} ; 15-20$ return to $0 \% \mathrm{ACN}$. An example of chromatogram obtained is reported in Figure 1.

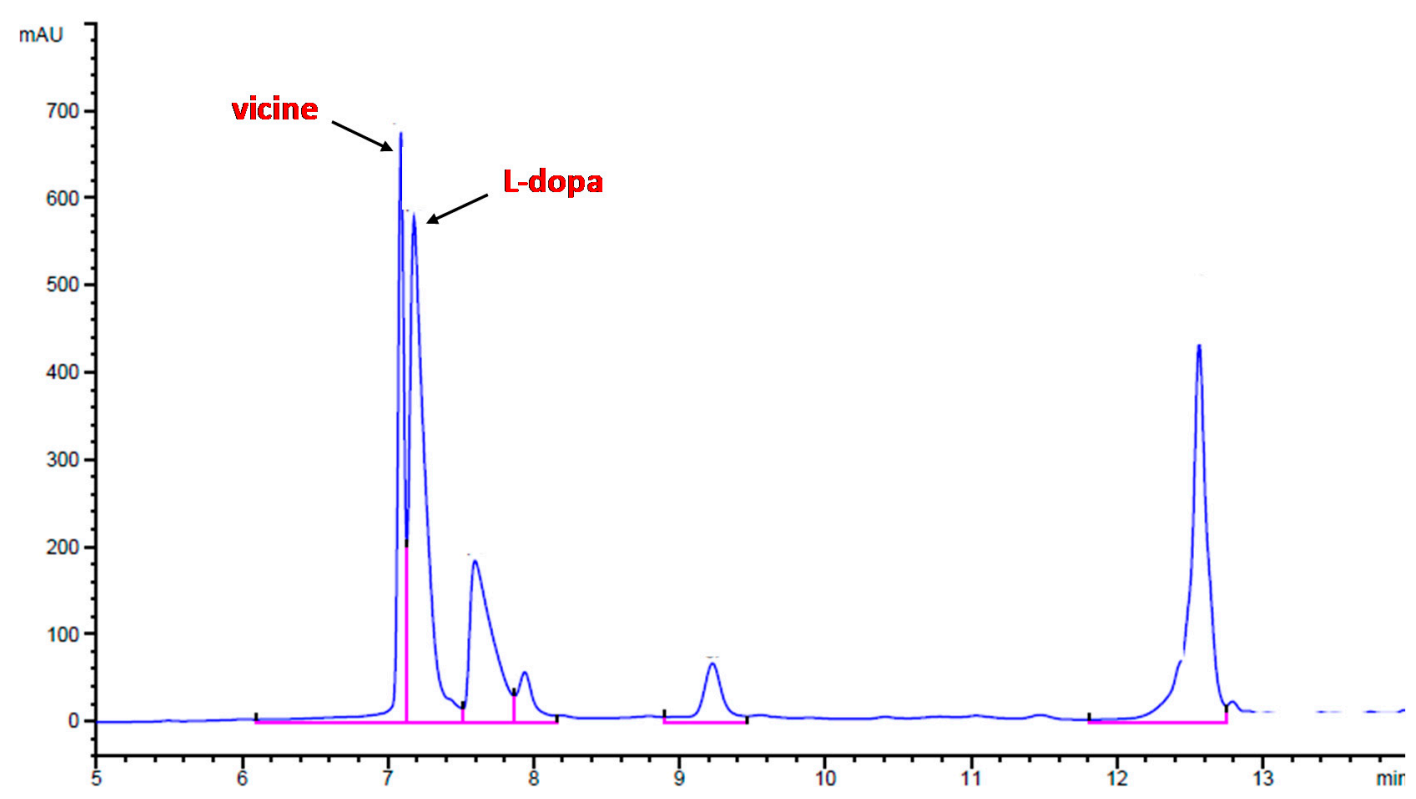

Figure 1. Example of chromatogram obtained after HPLC analysis for the determination of vicine and L-dopa contents.

\subsection{Statistical Analysis}

The two-way analysis of variance (ANOVA) was performed by using the GLM procedure (SAS software, Version 9.1) and applying a split-plot design with plant density and genotype as main factors. The Student-Newman-Keuls (SNK) test was carried out to obtain the separation of means.

The principal component analysis (PCA) was performed by using the PRINCOMP procedure (SAS software, Cary, NC, USA). The data matrix fed to PCA was made up of 12 observations-2 plant density (high and low) $\times 6$ genotypes (Extra-early purple, Aguadulce supersimonia, FV5, Iambola, San Francesco and Cegliese) - and 19 variables $\left(\mathrm{L}, a^{*}, b^{*}, \mathrm{~h}^{\circ}, \mathrm{C}\right.$, dry matter, whole pods yield, percentage of hulls per pod, TP, titratable acidity, TSS, $\mathrm{pH}$, proteins content, ascorbic acid, chlorophyll A and B, carotenoids, vicine and L-dopa,).

\section{Results}

For all the measured parameters, the ANOVA reveals that the interaction between plant density and genotype was not significant.

\subsection{Yield and Colour Traits}

Regarding the yield of whole pods, in all cases no significant differences were found between genotypes (Table 1). At the same time, by using the high plant density $\left(4.16\right.$ plants $\left.\mathrm{m}^{-2}\right)$ both the weight and the number of pods per unit of cultivated area were respectively 30.4 and $29.7 \%$ higher than the low density. On the other hand, independently of the plant density, Aguadulce supersimonia showed the highest value of mean pod weight, which resulted 30\% higher than Cegliese and 14\% than 
all other genotypes (Table 1). At the same time, FV5 showed a percentage of hulls higher of about $5 \%$ than Extra-early purple without any differences in comparison with other genotypes (Table 1).

Table 1. Main effects of plant density and genotypes on cumulative whole pod production and percentage of hulls. For each parameter are reported mean values \pm standard deviation.

\begin{tabular}{|c|c|c|c|c|}
\hline & \multicolumn{2}{|c|}{ Cumulative Whole Pods Yield } & \multirow{2}{*}{$\frac{\text { Mean Pod Weight }}{(\mathrm{g})}$} & \multirow{2}{*}{$\begin{array}{c}\text { Hulls } \\
(\%)\end{array}$} \\
\hline & (Number $\mathrm{m}^{-2}$ ) & $\left(\mathrm{g} \mathrm{m}^{-2}\right)$ & & \\
\hline \multicolumn{5}{|l|}{ Density (Plants $\mathrm{m}^{-2}$ ) } \\
\hline 4.16 & $86.3 \pm 16.0$ & $1794 \pm 373$ & $20.7 \pm 1.7$ & $74.7 \pm 4.6$ \\
\hline 2.08 & $66.5 \pm 16.5$ & $1376 \pm 403$ & $20.6 \pm 2.4$ & $74.5 \pm 4.6$ \\
\hline \multicolumn{5}{|l|}{ Genotype } \\
\hline Aguadulce supersimonia & $78.6 \pm 23.0$ & $1839 \pm 510$ & $23.5 \pm 2.1 \mathrm{a}$ & $74.0 \pm 4.5 \mathrm{ab}$ \\
\hline Extra-early purple & $86.4 \pm 22.1$ & $1737 \pm 502$ & $20.0 \pm 1.0 \mathrm{~b}$ & $73.1 \pm 5.9 \mathrm{~b}$ \\
\hline Cegliese & $70.1 \pm 23.7$ & $1275 \pm 487$ & $18.0 \pm 1.1 \mathrm{c}$ & $73.7 \pm 4.7 \mathrm{ab}$ \\
\hline FV5 & $73.0 \pm 15.3$ & $1529 \pm 352$ & $20.9 \pm 0.7 b$ & $76.8 \pm 4.0 \mathrm{a}$ \\
\hline Iambola & $73.0 \pm 11.4$ & $1502 \pm 309$ & $20.4 \pm 1.4 b$ & $74.5 \pm 4.2 \mathrm{ab}$ \\
\hline San Francesco & $77.4 \pm 18.8$ & $1627 \pm 372$ & $21.1 \pm 0.8 b$ & $75.6 \pm 3.8 \mathrm{ab}$ \\
\hline \multicolumn{5}{|l|}{ Significance } \\
\hline Density & * & $*$ & ns & ns \\
\hline Genotype & ns & ns & $* * *$ & * \\
\hline Density ${ }^{*}$ Genotype & ns & ns & $\mathrm{ns}$ & ns \\
\hline
\end{tabular}

Significance: $\mathrm{ns}=$ not significant; ${ }^{*}$ significant for $p \leq 0.05$. Different letters indicate statistically significant differences at $p=0.05$. Harvesting dates: $10 / 4 / 2018,18 / 4 / 2018,24 / 4 / 2018,5 / 4 / 2018$.

$\mathrm{L}, a^{*}, b^{*}$ and $\mathrm{C}$ values were, respectively, $52.7,-17.5,34.5$ and 38.7 without any differences between plant densities and genotypes (Table 2). Independently of the plant density, the $\mathrm{h}^{\circ}$ value in Cegliese was higher of about 0.5-1.0 unit than in Extra-early purple, Iambola and San Francesco (Table 2).

Table 2. Main effects of plant density and genotypes on CIELab colour traits ( $\mathrm{L}, a^{*}, b^{*}, \mathrm{~h}^{\circ}$ and C) of fava hulls as unconventional vegetable. For each parameter are reported mean values \pm standard deviation.

\begin{tabular}{|c|c|c|c|c|c|}
\hline & $\mathbf{L}$ & $a^{*}$ & $b^{*}$ & $\mathbf{h}^{\circ}$ & $\mathrm{C}$ \\
\hline \multicolumn{6}{|l|}{ Density (Plants $\mathrm{m}^{-2}$ ) } \\
\hline 4.16 & $52.9 \pm 2.1$ & $-17.7 \pm 0.8$ & $34.8 \pm 1.4$ & $117.0 \pm 0.6$ & $39.0 \pm 1.6$ \\
\hline 2.08 & $52.6 \pm 2.2$ & $-17.4 \pm 0.7$ & $34.2 \pm 1.2$ & $117.0 \pm 0.7$ & $38.4 \pm 1.3$ \\
\hline \multicolumn{6}{|l|}{ Genotype } \\
\hline Aguadulce supersimonia & $53.4 \pm 2.8$ & $-17.2 \pm 0.8$ & $33.7 \pm 1.3$ & $117.1 \pm 0.5 \mathrm{ab}$ & $37.8 \pm 1.5$ \\
\hline Extra-early purple & $53.9 \pm 2.5$ & $-17.3 \pm 0.8$ & $35.0 \pm 1.3$ & $116.4 \pm 0.7 \mathrm{c}$ & $39.0 \pm 1.5$ \\
\hline Cegliese & $52.1 \pm 2.3$ & $-17.9 \pm 1.1$ & $34.3 \pm 1.6$ & $117.5 \pm 0.6 \mathrm{a}$ & $38.7 \pm 1.9$ \\
\hline FV5 & $51.9 \pm 1.2$ & $-17.8 \pm 0.6$ & $34.7 \pm 1.2$ & $117.2 \pm 0.5 \mathrm{ab}$ & $39.1 \pm 1.3$ \\
\hline Iambola & $52.6 \pm 1.8$ & $-17.4 \pm 0.6$ & $34.7 \pm 1.3$ & $116.7 \pm 0.4 b c$ & $38.8 \pm 1.4$ \\
\hline San Francesco & $52.5 \pm 1.8$ & $-17.6 \pm 0.5$ & $34.6 \pm 1.2$ & $116.9 \pm 0.4 b$ & $38.9 \pm 1.2$ \\
\hline
\end{tabular}

\begin{tabular}{llllll}
\hline Significance & & & & \\
Density & $\mathrm{ns}$ & $\mathrm{ns}$ & $\mathrm{ns}$ & $\mathrm{ns}$ & $\mathrm{ns}$ \\
Genotype & $\mathrm{ns}$ & $\mathrm{ns}$ & $\mathrm{ns}$ & $* *$ & $\mathrm{~ns}$ \\
Density*Genotype & $\mathrm{ns}$ & $\mathrm{ns}$ & $\mathrm{ns}$ & $\mathrm{ns}$ & $\mathrm{ns}$ \\
\hline
\end{tabular}

Significance: $\mathrm{ns}=$ not significant; ${ }^{* *}$ significant for $p \leq 0.01$. Different letters indicate statistically significant differences at $p=0.05$.

\subsection{Chemical Traits}

The $\mathrm{pH}$ value in Aguadulce supersimonia was 5\% higher than Extra-early purple, Cegliese and Iambola, while no differences were found between Aguadulce supersimonia and other genotypes (Table 3). The value of TSS, titratable acidity, DW and protein content were, respectively, 7.4 ( ${ }^{\circ}$ Brix),

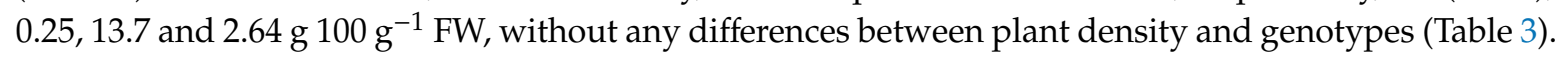


Table 3. Main effects of plant density and genotypes on $\mathrm{pH}$, total soluble solids (TSS) titratable acidity (TA), dry weight and protein content of fava hulls as unconventional vegetable. For each parameter are reported mean values \pm standard deviation.

\begin{tabular}{|c|c|c|c|c|c|}
\hline & $\mathrm{pH}$ & TSS & TA & Dry Weight & Protein \\
\hline & & $\left({ }^{\circ}\right.$ Brix) & & $\left(\mathrm{g} 100 \mathrm{~g}^{-1} \mathrm{FW}\right)$ & \\
\hline \multicolumn{6}{|l|}{ Density (Plants $\mathrm{m}^{-2}$ ) } \\
\hline 4.16 & $5.5 \pm 0.1$ & $7.5 \pm 1.1$ & $0.25 \pm 0.05$ & $13.5 \pm 1.0$ & $2.63 \pm 0.30$ \\
\hline 2.08 & $5.5 \pm 0.1$ & $7.3 \pm 0.9$ & $0.26 \pm 0.06$ & $14.0 \pm 1.8$ & $2.66 \pm 0.34$ \\
\hline \multicolumn{6}{|l|}{ Genotype } \\
\hline Aguadulce Supersimonia & $5.7 \pm 0.1 \mathrm{a}$ & $6.9 \pm 0.6$ & $0.24 \pm 0.06$ & $13.1 \pm 0.7$ & $2.46 \pm 0.20$ \\
\hline Extra-early purple & $5.4 \pm 0.1 \mathrm{~b}$ & $7.9 \pm 0.9$ & $0.25 \pm 0.05$ & $14.9 \pm 1.5$ & $2.80 \pm 0.42$ \\
\hline Cegliese & $5.4 \pm 0.2 b$ & $6.8 \pm 1.4$ & $0.26 \pm 0.08$ & $13.9 \pm 0.7$ & $2.79 \pm 0.32$ \\
\hline FV5 & $5.5 \pm 0.1 \mathrm{ab}$ & $7.3 \pm 0.7$ & $0.22 \pm 0.04$ & $13.8 \pm 2.4$ & $2.64 \pm 0.37$ \\
\hline Iambola & $5.4 \pm 0.2 b$ & $7.7 \pm 1.0$ & $0.29 \pm 0.02$ & $14.1 \pm 0.8$ & $2.75 \pm 0.15$ \\
\hline San Francesco & $5.5 \pm 0.1 \mathrm{ab}$ & $7.9 \pm 0.7$ & $0.26 \pm 0.06$ & $12.8 \pm 1.3$ & $2.44 \pm 0.27$ \\
\hline \multicolumn{6}{|l|}{ Significance } \\
\hline Density & ns & ns & ns & ns & ns \\
\hline Genotype & $* *$ & ns & ns & ns & ns \\
\hline Density*Genotype & ns & ns & ns & ns & ns \\
\hline
\end{tabular}

Significance: $\mathrm{ns}=$ not significant; ${ }^{* *}$ significant for $p \leq 0.01$. Different letters indicate statistically significant differences at $p=0.05$.

As for the content of chlorophylls, total carotenoids, ascorbic acid, total phenols, vicine and L-dopa, in no case did plant density affect the values (Table 4). The chlorophyll a content was $75 \%$ higher in Cegliese than in Extra-early purple and FV5, while no differences were found between Cegliese and other genotypes. The content of chlorophyll $\mathrm{b}$ in Cegliese was higher of about $60 \%$ than all other genotypes with the exception of Aguadulce supersimonia (Table 4). Cegliese showed also a total carotenoid content 53\% higher than in Extra-early purple and FV5, while no differences were found between Cegliese and other genotypes. As for the ascorbic acid, Extra-early purple and San Francesco showed a content higher of about $78 \%$ than all other genotypes (Table 4 ). The average content of vicine and L-dopa was, respectively, of 12.4 and $170.7 \mathrm{mg} 100 \mathrm{~g}^{-1} \mathrm{FW}$, without any differences between genotypes (Table 4).

Table 4. Main effects of plant density and genotypes on the content of chlorophyll (Chl) a and b, total carotenoids (TC), ascorbic acid, total phenols and vicine and L-dopa of fava pods as unconventional vegetable. Total phenols content is expressed as gallic acid equivalent. For each parameter are reported mean values \pm standard deviation.

\begin{tabular}{|c|c|c|c|c|c|c|c|}
\hline & Chl a & Chl b & TC & $\begin{array}{c}\text { Ascorbic } \\
\text { Acid }\end{array}$ & $\begin{array}{c}\text { Total } \\
\text { Phenols }\end{array}$ & Vicine & L-Dopa \\
\hline & \multicolumn{3}{|c|}{$\left(\mu g^{-1} F W\right)$} & \multicolumn{4}{|c|}{$\left(\mathrm{mg} 100 \mathrm{~g}^{-1} \mathrm{FW}\right)$} \\
\hline 4.16 & $17.0 \pm 5.4$ & $6.7 \pm 2.7$ & $7.2 \pm 1.8$ & $42 \pm 18$ & $563 \pm 129$ & $14.5 \pm 5.3$ & $178.4 \pm 32.2$ \\
\hline 2.08 & $16.2 \pm 4.9$ & $7.2 \pm 1.9$ & $7.0 \pm 1.9$ & $37 \pm 10$ & $602 \pm 114$ & $10.4 \pm 3.6$ & $163.1 \pm 27.3$ \\
\hline \multicolumn{8}{|l|}{ Variety } \\
\hline Extra-early purple & $12.8 \pm 3.1 \mathrm{~b}$ & $4.5 \pm 2.6 c$ & $6.0 \pm 1.4 b$ & $53 \pm 7 a$ & $546 \pm 113 \mathrm{ab}$ & $14.6 \pm 6.8$ & $185.5 \pm 33.7$ \\
\hline Cegliese & $22.8 \pm 5.4 \mathrm{a}$ & $9.6 \pm 2.0 \mathrm{a}$ & $9.1 \pm 2.3 \mathrm{a}$ & $33 \pm 2 b$ & $638 \pm 50 \mathrm{a}$ & $10.4 \pm 3.4$ & $176.3 \pm 21.6$ \\
\hline FV5 & $13.3 \pm 3.0 \mathrm{~b}$ & $6.2 \pm 0.9 \mathrm{bc}$ & $5.9 \pm 1.2 b$ & $30 \pm 3 b$ & $570 \pm 120 \mathrm{ab}$ & $13.7 \pm 4.5$ & $182.8 \pm 28.5$ \\
\hline Iambola & $16.3 \pm 4.2 \mathrm{ab}$ & $6.9 \pm 1.1 \mathrm{bc}$ & $7.1 \pm 1.3 \mathrm{ab}$ & $30 \pm 3 b$ & $649 \pm 77 \mathrm{a}$ & $10.3 \pm 3.4$ & $165.7 \pm 44.7$ \\
\hline San Francesco & $16.2 \pm 3.7 \mathrm{ab}$ & $6.3 \pm 1.7 \mathrm{bc}$ & $7.2 \pm 1.7 \mathrm{ab}$ & $58 \pm 20 \mathrm{a}$ & $651151 \mathrm{a}$ & $12.6 \pm 1.7$ & $155.7 \pm 26.4$ \\
\hline \multicolumn{8}{|l|}{ Significance } \\
\hline
\end{tabular}

Significance: $\mathrm{ns}=$ not significant; ${ }^{* *}$ and ${ }^{* * *}$ significant for $p \leq 0.01$ and $p \leq 0.001$, respectively. Different letters indicate statistically significant differences at $p=0.05$. 


\subsection{Principal Component Analysis}

The first five principal components explained $88 \%$ of the total variance, with principal component 1 (PC1) and principal component 2 (PC2) accounting for 33.1 and 18.5\%, respectively (Figure 2). PC1 was mainly correlated by colour parameters (positively by $b^{*}$ and $C$, and negatively by $h^{\circ}, a^{*}$ and $\mathrm{L}$ ) as well as by TTS, L-dopa, vicine and ascorbic acid (positively) and by chlorophylls, total carotenoids and $\mathrm{pH}$ (negatively-Figure 2). PC2 was influenced mainly by total carotenoids, chlorophylls, titratable acidity, proteins content and L-dopa (positively) and by yield and $\mathrm{pH}$ (negatively-Figure 2).

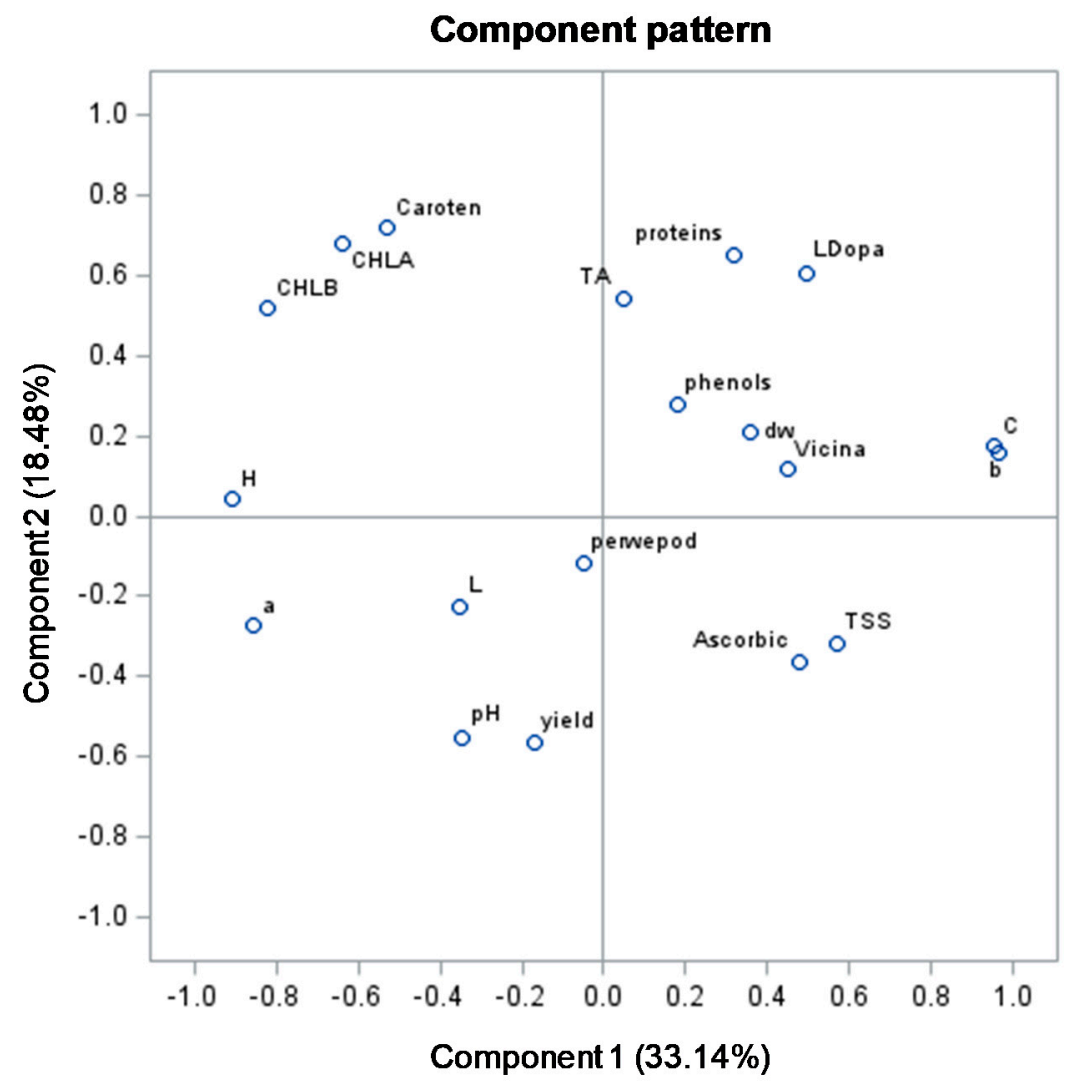

Figure 2. Loading plot for principal components 1 and 2, describing variation in physical and chemical parameters of six fava pod genotypes as unconventional vegetables at two plant density. $\mathrm{L}, \mathrm{a}, \mathrm{b}, \mathrm{C}$ and $\mathrm{h}$ denote $\mathrm{L}, a^{*}, b^{*}, \mathrm{C}$ and $\mathrm{h}^{\circ}$, respectively as colour parameters; dw, dry weight; TA, titratable acidity; TSS, total soluble content; Caroten, total carotenoids; phenols, total phenols; proteins, proteins content; CHL, chlorophyll; Ascorbic, ascorbic acid; yield, whole pods yield; perwepod, percentage of hulls per pod.

The product distribution in the score plot (Figure 3) revealed a separation between Cegliese and all other genotypes, the former located on the positive side of PC2 and negative side of PC1. Similarly, the score plot revealed a separation between Aguadulce supersimonia and all other genotypes, the former located on the negative side of both PC1 and PC2 (Figure 3). Moreover, regarding the commercial varieties there was an evident distinction between Extra-early purple and Aguadulce supersimonia, since the former was the only commercial variety located on the positive side of PC1 (Figure 3). 
Component scores

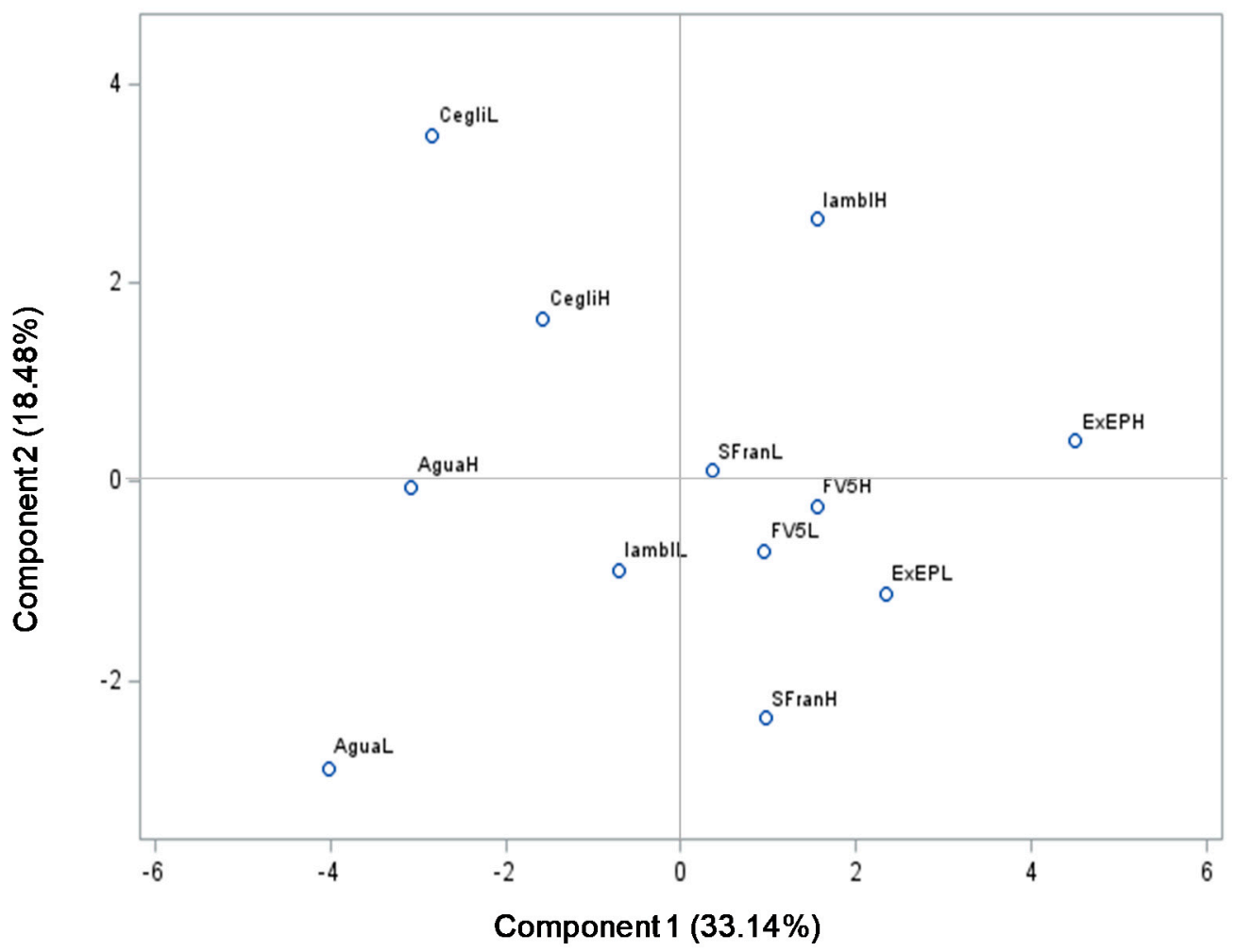

Figure 3. Score plot for principal components 1 and 2, describing variation in physical and chemical parameters of six fava pods genotypes as unconventional vegetables at two plant density. For each genotype, letters $\mathrm{H}$ and L indicate high and low plant density, respectively. SFran, San Francesco; ExEP, Extra-early purple; Iambl, Iambola; Agua, Aguadulce supersimonia; Cegli, Cegliese.

\section{Discussion}

In this study, for the first time, some nutritional traits of faba hulls from fresh pods were assessed in order to evaluate the potential of this unconventional vegetable as a new functional food. We compared several Vicia faba L. genotypes and two different plant densities to analyse also the effects of agrobiodiversity and growth conditions on the content of some nutritional and bioactive compounds. Results suggest that a great part of variation was almost exclusively due to genotypes, while only in a few cases we found differences due to the plant density. From a yield point of view, we observed that, independently of the genotype, the higher the plant density the higher was the pod yield per unit area. At the same time, the percentage of hulls was not affected by plant density, while only small differences were found between genotypes highlighting an average value of $75 \%$. These results confirm the great benefit of considering faba hulls as unconventional vegetables instead of as a by-product, since they represent about three-quarters of the whole faba pod production.

Colour can be considered as an important quality trait of food products since it may influence the choice of consumers. Regarding vegetables, colour is associated with the change in plant tissue from green to other colours, as a consequence of chlorophylls break down and accumulation of other pigments. In this context, chlorophylls concentration in vegetable tissue can be the main factor which affects the colour in fava hulls. In our study, we found a higher $\mathrm{h}^{\circ}$ (hue) value for Cegliese in comparison with Extra-early purple, independently of the plant density (Table 2). Hue value can be defined as a qualitative characteristic according to which colours are described as red, yellow, green, etc. More specifically, an $\mathrm{h}^{\circ}$ value of 90 corresponds to yellow, while a value of 180 corresponds to green. In our study, the $h^{\circ}$ value ranges between 116 and 117 (Table 2), thus faba hull hues can be described as between yellow and greenish. It is important to highlight that the $\mathrm{h}^{\circ}$ value trend was similar to the 
one of chlorophylls content, because Cegliese showed a higher value than Extra-early purple (Table 4). Therefore, the lower $h^{\circ}$ value in Extra-early purple indicates a hue which can be described as less green than Cegliese, probably due to its lower chlorophylls content. The trend for the $h^{\circ}$ value and chlorophylls content was confirmed by PCA, since $h^{\circ}$ and chlorophylls ( $a$ and $b$ ) were located on the upper left quadrant (Figure 2). At the same time, Cegliese at high and low density, both located on the same quadrant, were positively correlated with $\mathrm{h}^{\circ}$ and chlorophylls, while Extra-early purple at low and high density, both located to the right in PC1 plot far from the origin, were inversely correlated with $\mathrm{h}^{\circ}$ and chlorophylls (Figure 3 ).

From a nutritional point of view, faba hulls show an average protein content of about $2.6 \mathrm{~g}$ $100 \mathrm{~g}^{-1} \mathrm{FW}$, without any differences between plant densities and genotypes. In a study aimed to evaluate the quality of immature fresh seeds in some landraces and commercial varieties of Vicia faba

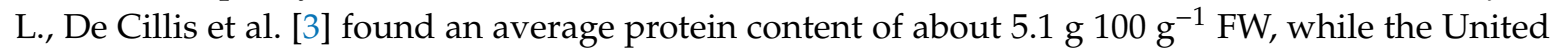

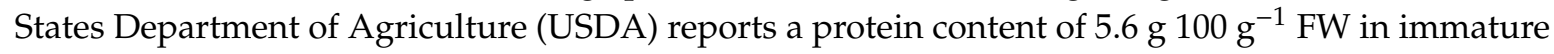
seeds of faba beans [14], suggesting faba seeds contain higher protein amounts than the hulls. On the other hand, it should be considered that faba hulls contain a protein amount slightly higher than fresh pods of other legumes such as snap beans, since their average protein content is of about $1.8{\mathrm{~g} 100 \mathrm{~g}^{-1}}^{-1}$ FW $[15,16]$.

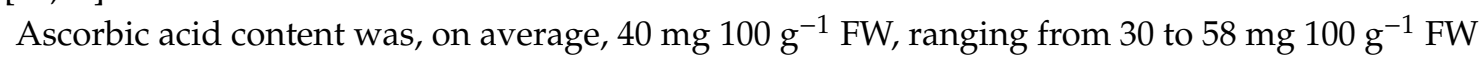
between genotypes (Table 4). This vitamin is essential for humans, considering its numerous functions for human health [17]. Ascorbic acid content in fava hulls appears tens of times lower than ones

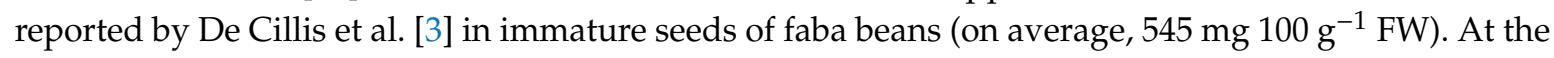
same time, ascorbic acid content in faba hulls seems to be similar in comparison with one reported for immature seeds of faba beans ( $33 \mathrm{mg} 100 \mathrm{~g}^{-1} \mathrm{FW}$ ) [14]. Furthermore, it should be considered that faba hulls contain an ascorbic acid content at least two times higher than fresh pods of other legumes such as snap beans, since their average content of ascorbic acid is of about $14 \mathrm{mg} 100 \mathrm{~g}^{-1} \mathrm{FW}[15,16]$. Therefore, our results suggest that faba hulls can be judged a good source of ascorbic acid, considering its recommended daily intake of $45-70 \mathrm{mg}$ [18].

Phenols represent an important group of antioxidants for humans. In our study the total phenols content was significantly different among the genotypes, ranging from 443 to $646 \mathrm{mg} 100 \mathrm{~g}^{-1} \mathrm{FW}$ (Table 4). Although the literature lacks information regarding the content of phenols in faba hulls, it is interesting to note that De Cillis et al. [3] found an average total phenols content of $551 \mathrm{mg} 100 \mathrm{~g}^{-1}$ FW in immature fresh seeds of faba bean. On the other hand, other authors [19] found an amount

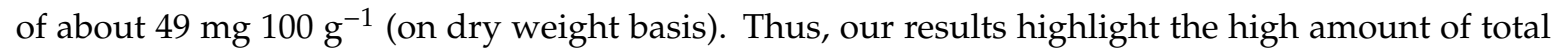
phenols in fresh faba products, not only in seeds but also in hulls. To this end, it could be interesting to compare also the total phenols content between faba hulls and other common vegetables. In a study aimed to evaluate the phenols content in 23 vegetables, Vinson et al. [20] found the highest content

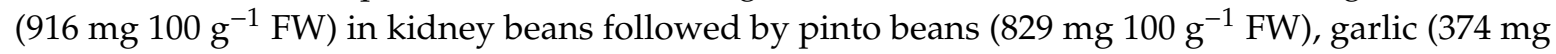
$100 \mathrm{~g}^{-1} \mathrm{FW}$ ), beet (236 mg $\left.100 \mathrm{~g}^{-1} \mathrm{FW}\right)$, corn (142 mg $\left.100 \mathrm{~g}^{-1} \mathrm{FW}\right)$ and broccoli (105 mg $\left.100 \mathrm{~g}^{-1} \mathrm{FW}\right)$. In all other cases (asparagus, snap bean, kidney bean, cabbage, carrot, cauliflower, celery, cucumber. lettuce, mushroom, red and yellow onion, bell pepper, potato, green squash, spinach, sweet potato and tomato), the phenols content was lower than $100 \mathrm{mg} 100 \mathrm{~g}^{-1} \mathrm{FW}$. Therefore, the results of the present study show that faba hulls can contain an amount of phenols at least five times higher than several other common vegetables hence suggesting their consumption for the recommended intake of this important group of antioxidants.

Vicine is a pyrimidine $\beta$-glycoside present in the cotyledons of the faba bean, which is hydrolysed by the G6PD. This glycoside is a potential favism-inducing factor, since it can cause acute haemolysis in subjects affected by a deficiency of this enzyme due to a gene mutation. It is important to note that people affected by favism are always G6PD deficient, while not all people with a G6PD deficiency develop haemolysis after fava beans ingestion. Therefore, G6PD deficiency can be considered as a necessary cause of favism although it is a not sufficient cause. Moreover, the great majority of favism 
manifestations occurs in people with severely deficient variants of G6PD, while only in a few cases this disease has been observed in subjects with other G6PD variants [21]. Although convicine can cause the same problems in subjects affected by $\beta$-glucosidases deficiency, we decided to determinate only vicine content, considering that in Vicia faba L. convicine content is about half the vicine one [22,23]. In our study, the average content of vicine was $12.4 \mathrm{mg} 100 \mathrm{~g}^{-1} \mathrm{FW}$, without any difference between genotypes and plant density (Table 4). De Cillis et al. [3] reported a vicine content over $2000 \mathrm{mg} 100 \mathrm{~g}^{-1} \mathrm{DW}$ in immature seeds of faba beans, while other authors [24] reported a content ranging between 450 and 900 $100 \mathrm{~g}^{-1} \mathrm{DW}$. Our results highlight the much lower content of vicine in faba hulls $\left(90 \mathrm{mg} 100 \mathrm{~g}^{-1} \mathrm{DW}\right.$, on average) instead of faba seed, suggesting this unconventional vegetable as an alternative instead of faba seed for G6PD deficient subjects.

L-dopa, a precursor of dopamine, is considered a very important compound currently used to increase dopamine concentrations in patients affected by Parkinson's disease and dopamine-responsive dystonia [4]. It is well known that faba beans can be considered a natural source of L-dopa with an amount able to be pharmacologically active on subjects affected by Parkinson's disease [25]. Actually, some authors reported that the use of fresh fava beans as meal supplementation is effective as a means of reducing the levodopa off-period disability in patients with Parkinson's disease [26]. Other authors reported that in patients with Parkinson's disease who consumed fresh fava beans, the plasma L-dopa levels remain at higher levels for longer periods than in healthy subjects [27]. At the same time, it should be considered that high plasma levels of L-dopa gained through the consumption of faba beans are comparable to the ones obtained by using synthetic L-dopa preparations [28]. It is important to highlight that the increase of the L-dopa plasma level caused by ingestion of faba beans can improve motor symptoms without side effects such as intense dyskinesia [4]. Nevertheless, L-dopa concentration in faba beans may vary markedly based on genotype, plant density, environment conditions, as well as several other factors. Although the literature lacks information regarding the content of L-dopa in faba hulls, it is interesting to note that De Cillis et al. [3] found a L-dopa content in fresh faba seeds ranging

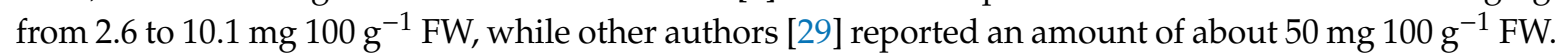
In the present study L-dopa was quantified in faba hulls, and we found an average content of about $170 \mathrm{mg} 100 \mathrm{~g}^{-1} \mathrm{FW}$, without differences between genotypes and plant densities (Table 4). Therefore, our results highlight the very high content of L-dopa in faba hulls, suggesting their consumption as a suitable foodstuff for patients with Parkinson's disease.

\section{Conclusions}

In this study, for the first time, some nutritional traits of faba hulls from fresh pods of six genotypes were assessed in order to evaluate the potential of this unconventional vegetable as a new functional food. From a yield point of view, our results highlight that faba hulls represent about $75 \%$ of the total fava bean yield from the field, suggesting the great advantage of considering these plant parts as unconventional vegetables instead of a by-product. As for the nutritional traits, all genotypes showed a low content of the antinutritional factor vicine, and a very high content of phenols and L-dopa, a dopamine precursor used for Parkinson's disease treatment. In conclusion, this study highlights the good potential of faba hulls as an unconventional vegetable, suggesting its use as a new functional food in the daily diet and also for patients with Parkinson's disease. Future research activities may be aimed to assess the use of faba hulls as a meal supplementation in patients with Parkinson's disease through clinical trials, as well as the possibility of processing hull-based food products with standardized L-dopa content.

Author Contributions: Conceptualization, M.R. and P.S.; data curation, F.D.C., E.A., B.L., M.R., and P.S.; formal analysis, P.S.; funding acquisition, P.S.; investigation, F.D.C., M.R., and P.S.; project administration, P.S.; resources, F.D.C., E.A., B.L., M.R., and P.S.; supervision, M.R., and P.S.; validation, F.D.C., M.R., and P.S.; visualization, F.D.C., M.R., and P.S.; writing—original draft, M.R.; writing—review and editing, F.D.C., E.A., B.L., M.R., and P.S. All authors have read and agreed to the published version of the manuscript. 
Funding: This research was funded by Regione Puglia Administration under Rural Development Program 2014-2020-Project "Biodiversity of vegetable crops in Puglia (BiodiverSO)", Measure 10, Sub measure 10.2, Operation 1 "Program for the conservation and the valorisation of the genetic resources in agriculture".

Acknowledgments: The authors thank Nicola Gentile for providing technical assistance during the experiment.

Conflicts of Interest: The authors declare no conflict of interest.

\section{References}

1. Wolosiak, R.; Worobiej, E.; Piecyk, M.; Druzynska, B.; Nowak, D.; Lewicki, P.P. Activities of amine and phenolic antioxidants and their changes in broad beans (Vicia faba) after freezing and steam cooking. Int. J. Food Sci. Technol. 2009, 45, 29-37. [CrossRef]

2. dos Santos Rosa, E.A.; Savvas, D.; Barros, A.; Balliu, A.; Karapanos, I.; Weiss, J.; Gutiérrez-Cortines, M.E.; Ntatsi, G. The quality of leguminous vegetables as influenced by preharvest factors. Sci. Hortic. (Amst.) 2018, 232, 191-205. [CrossRef]

3. De Cillis, F.; Leoni, B.; Massaro, M.; Renna, M.; Santamaria, P. Yield and quality of faba bean (Vicia faba L. var. major) genotypes as a vegetable for fresh consumption: A comparison between Italian landraces and commercial varieties. Agriculture 2019, 9, 253. [CrossRef]

4. Korczyn, A.D.; Graff, E.; Rabey, J.M.; Vered, Y.; Shabtai, H. Improvement of parkinsonian features correlate with high plasma levodopa values after broad bean (Vicia faba) consumption. J. Neurol. Neurosurg. Psychiatry 2008, 55, 725-727. [CrossRef]

5. Cappellini, M.; Fiorelli, G. Glucose-6-phosphate dehydrogenase deficiency. Lancet 2008, 371, 64-74. [CrossRef]

6. Tesco Frozen Broad Beans. Available online: https://www.tesco.com/groceries/en-GB/products/282412496 (accessed on 6 December 2019).

7. Bonduelle Canned Broad Beans. Available online: https://hollandshopper.nl/Bonduelle-tuinboontjes (accessed on 6 December 2019).

8. Renna, M.; Signore, A.; Paradiso, V.M.; Santamaria, P. Faba greens, globe artichoke's offshoots, crenate broomrape and summer squash greens: Unconventional vegetables of Puglia (Southern Italy) with good quality traits. Front. Plant Sci. 2018, 9, 1-13. [CrossRef] [PubMed]

9. Bianco, V.V.; Renna, M.; Santamaria, P. Ortaggi Liberati L'ebook. Dieci Prodotti Straordinari Della Biodiversità Pugliese ... e Qualcosa in Più.; Università degli Studi di Bari Aldo Moro: Bari, Italy, 2018; ISBN 978-88-6629-030-8.

10. Signore, A.; Renna, M.; Santamaria, P. Agrobiodiversity of vegetable crops: Aspect, needs, and future perspectives. Annu. Plant Rev. Online 2019, 2, 1-24. [CrossRef]

11. AOAC Official Methods of Analysis of AOAC International, 16th ed.; AOAC International: Arlington, VA, USA, 1995.

12. Renna, M.; Gonnella, M.; Giannino, D.; Santamaria, P. Quality evaluation of cook-chilled chicory stems (Cichorium intybus L., Catalogna group) by conventional and sous vide cooking methods. J. Sci. Food Agric. 2014, 94, 656-665. [CrossRef] [PubMed]

13. Albanese, D.; Russo, L.; Cinquanta, L.; Brasiello, A.; Di Matteo, M. Physical and chemical changes in minimally processed green asparagus during cold-storage. Food Chem. 2007, 101, 274-280. [CrossRef]

14. USDA Broadbeans, Immature Seeds, Raw. Available online: https://fdc.nal.usda.gov/fdc-app.html\#/fooddetails/170377/nutrients (accessed on 15 October 2019).

15. USDA Beans, Snap, Green, Raw. Available online: https:/fdc.nal.usda.gov/fdc-app.html\#/food-details/ 169961/nutrients (accessed on 26 November 2019).

16. USDA Beans, Snap, Yellow, Raw. Available online: https://fdc.nal.usda.gov/fdc-app.html\#/food-details/ 169320/nutrients (accessed on 27 November 2019).

17. Harris, J.R. Ascorbic Acid: Biochemistry and Biomedical Cell Biology; Plenum Press: New York, NY, USA, 1996; ISBN 1461303257.

18. European Food Safety Authority. Tolerable Upper Intake Levels for Vitamins and Minerals; European Food Safety Authority: Parma, Italy, 2006; ISBN 9291990140.

19. Giusti, F.; Caprioli, G.; Ricciutelli, M.; Vittori, S.; Sagratini, G. Determination of fourteen polyphenols in pulses by high performance liquid chromatography-diode array detection (HPLC-DAD) and correlation study with antioxidant activity and colour. Food Chem. 2017, 221, 689-697. [CrossRef] [PubMed] 
20. Vinson, J.A.; Hao, Y.; Su, X.; Zubik, L. Phenol antioxidant quantity and quality in foods: Vegetables. J. Agric. Food Chem. 1998, 46, 3630-3634. [CrossRef]

21. Al Muzrakchi, A.; Gehani, A.A. G6PD deficiency. Qatar Med. J. 2004, 13, 46. [CrossRef]

22. Goyoaga, C.; Burbano, C.; Cuadrado, C.; Varela, A.; Guillamón, E.; Pedrosa, M.M.; Muzquiz, M. Content and distribution of vicine, convicine and L-dopa during germination and seedling growth of two Vicia faba L. varieties. Eur. Food Res. Technol. 2008, 227, 1537-1542. [CrossRef]

23. Pulkkinen, M.; Gautam, M.; Lampi, A.-M.; Ollilainen, V.; Stoddard, F.; Sontag-Strohm, T.; Salovaara, H.; Piironen, V. Determination of vicine and convicine from faba bean with an optimized high-performance liquid chromatographic method. Food Res. Int. 2015, 76, 168-177. [CrossRef]

24. Gardiner, E.E.; Marquardt, R.R.; Kemp, G. Variation in vicine and convicine concentration of faba bean genotypes. Can. J. Plant Sci. 1982, 62, 589-592. [CrossRef]

25. Ramírez-Moreno, J.M.; Salguero Bodes, I.; Romaskevych, O.; Duran-Herrera, M.C. Consumo de habas (Vicia faba) y enfermedad de Parkinson: Una fuente natural de L-dopa a tener en cuenta. Neurología 2015, 30, 375-376. [CrossRef] [PubMed]

26. Hulya, A.; Sibel, E.; Sibel, O. Broad bean (Vicia Faba)—A natural source of L-dopa—Prolongs "on" periods in patients with Parkinson's disease who have "on-off" fluctuations. Mov. Disord. 2000, 15, 164-166.

27. Kempster, P.A.; Bogetic, Z.; Secombei, J.W.; Martin, H.D.; Balazs, N.D.; Wahlqvist, M.L. Motor effects of broad beans (Vicia faba) in Parkinson's disease: Single dose studies. Asia Pac. J. Clin. Nutr. 1993, 2, 85-89. [PubMed]

28. Rabey, J.M.; Vered, Y.; Shabtai, H.; Graff, E.; Korczyn, A.D. Improvement of parkinsonian features correlate with high plasma levodopa values after broad bean (Vicia faba) consumption. J. Neurol. Neurosurg. Psychiatry 1992, 55, 725-727. [CrossRef] [PubMed]

29. Vered, J.; Rabey, D.; Palevitch, I.; Grosskopf, A.; Harsat, A.; Yanowski, H.; Shabtai, E.; Graff, Y. Bioavailability of levodopa after consumption of Vicia faba seedlings by Parkinsonian patients and control subjects. Clin. Neuropharmacol. 1994, 17, 138-146. [CrossRef]

(C) 2020 by the authors. Licensee MDPI, Basel, Switzerland. This article is an open access article distributed under the terms and conditions of the Creative Commons Attribution (CC BY) license (http://creativecommons.org/licenses/by/4.0/). 